\section{First record of two Pentatomidae bugs from Chandoli area, Kolhapur, Maharashtra, India}

\author{
Hemant V. Ghate ${ }^{1}$, Girish P. Pathak ${ }^{2}$, Yogesh \\ Koli $^{3}$ \& Ganesh P. Bhawane ${ }^{4}$
}

${ }^{1}$ Head, ${ }^{2}$ Student, Department of Zoology, Modern College, Shivajinagar, Pune, Maharashtra 411005, India

${ }^{3}$ Research Fellow, ${ }^{4}$ Professor of Zoology, Department of Zoology, Shivaji University, Kolhapur, Maharashtra 416004, India

Email: ${ }^{1}$ hemantghate@gmail.com (corresponding author), ${ }^{2}$ pathak.giri172@gmail.com, ${ }^{3}$ yogesh14_1985@rediffmail.com, ${ }^{4}$ drgpbhawane@rediffmail.com

Casual collection of bugs from shrub vegetation near Chandoli National Park, Kolhapur District, Maharashtra state revealed the presence of two interesting pentatomid bugs. These two bugs have been identified as Andrallus spinidens (Fabricius, 1787) and Sabaeus humeralis (Dallas, 1851), based on information in Distant (1902). Both specimens are preserved in the Zoology Department, Modern College (Reg.No. are B-75 and B-76, respectively for Andrallus and Sabaeus).

Andrallus spinidens (Pentatomidae: Asopinae) is a well known predatory bug. Distant (1902), in 'Fauna of British India', had described it as

Date of publication (online): 26 April 2012

Date of publication (print): 26 April 2012

ISSN 0974-7907 (online) | 0974-7893 (print)

Editor: Alex Ramsay

Manuscript details:

Ms \# 02920

Received 21 August 2011

Final received 16 January 2012

Finally accepted 24 March 2012

Citation: Ghate, H.V., G.P. Pathak, Y. Koli \& G.P. Bhawane (2012) First record of two Pentatomidae bugs from Chandoli area, Kolhapur Maharashtra, India. Journal of Threatened Taxa 4(4): 2524-2528.

Copyright: ( Hemant V. Ghate, Girish P. Pathak, Yogesh Koli \& Ganesh P. Bhawane 2012. Creative Commons Attribution 3.0 Unported License. JoTT allows unrestricted use of this article in any medium for non-profit purposes reproduction and distribution by providing adequate credit to the authors and the source of publication.

Acknowledgement: Authors are grateful to the authorities of Modern College, Pune for facilities and encouragement. We also thank the personne from the Forest Department (Chandoli), for granting permission to work and collect insects near Chandoli National Park. Thanks are also due to the authorities of Shivaji University, Kolhapur, for providing facilities.

OPEN ACGESS | FREE DOWNLOAD
Audinetia spinidens. The recent nomenclature of Asopinae bugs has been given by Thomas (1994) and, accordingly, the current valid name of this species is Andrallus spinidens. Distant (1902) mentions the distribution of this bug in India from Sikkim, Assam, Khasi Hills, Bengal, Ranchi and Bangalore. We have not come across any published report of this bug from Maharashtra. This note extends the known distributional range of this species to the north of India, although the bug is distributed widely throughout southern Asia and is even found in 'Malaya Archipelago', China, Japan, and occurring west to Turkey and more recently, Greece. It occurs also in various parts of the Africa, Syria, Equatorial Guinea, Malawi, Madagascar, Australia, North America and Central America (Distant 1902; Thomas, 1992, 1994 Pericart 2010).

This bug is pale brownish overall with a distinct colour pattern, and is somewhat elongate in appearance (Image 1). As an Asopinae member, the bug possesses the typical robust and long rostrum with incrassated first joint. The diagnostic characters of this bug are: head long, lateral lobes (jugae) slightly longer than median lobe (tylus), moderately prolonged, head almost rectangular if eyes are not considered, coarsely punctured, especially the lateral lobes, punctures on lateral lobes dark black (Image 2). Antennae 5-segmented, $1^{\text {st }}$ antennal segment short, not reaching apex of the head, antennal segments dark brown with very fine setae, $4^{\text {th }}$ and $5^{\text {th }}$ segments with ochraceous base. Pronotum with anterior border concave behind the head but the posterior border more or less straight, antero-lateral margin crenulate, lateral angles each produced in straight subacute spines with a small spine at the base of long spine. Pronotum also distinctly sloping anteriorly and convex in the basal region, with a somewhat raised, pale coloured impunctate line joining the two lateral pronotal angles (Images $3 \mathrm{a}, \mathrm{b}$ ). Entire disc of pronotum covered with coarse black punctures, which in the anterior $1 / 4^{\text {th }}$ form a pattern in dense clusters around the calli, with heavy but distinct punctures across the rest of the pronotum. Scutellum long and slender, coarsely punctured, triangular gradually narrowing distally. The dark punctures on scutellum are so numerous that it appears darker than pronotum where punctures are well separated; 


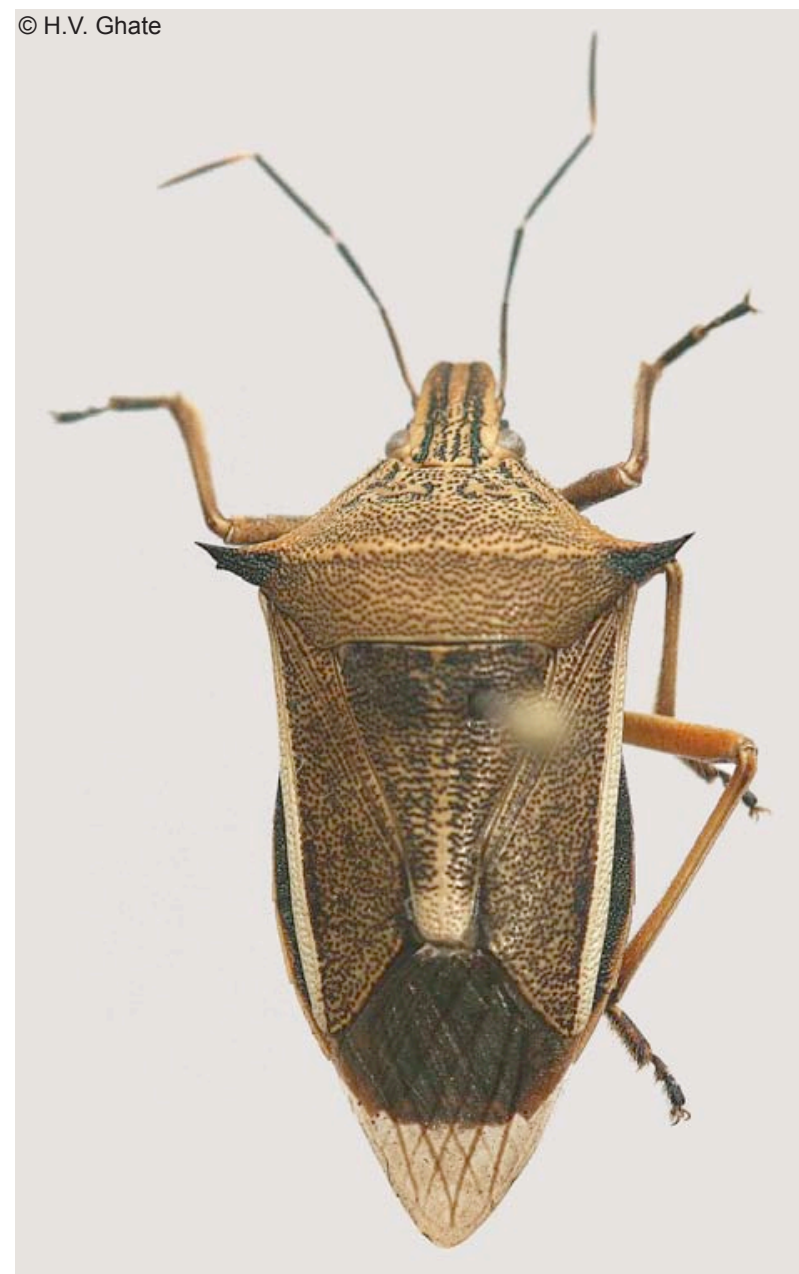

Image 1. Andrallus spinidens, dorsal view. Note the typical colour pattern and dark punctures on ochraceous body

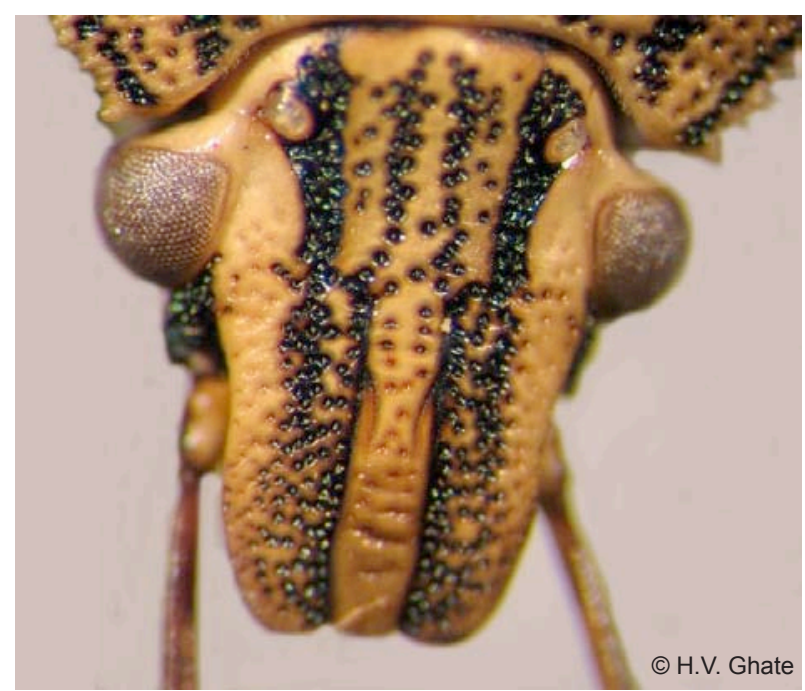

Image 2. Andrallus spinidens head, dorsal view showing a pattern of black punctures, large eyes and more or less elongated head

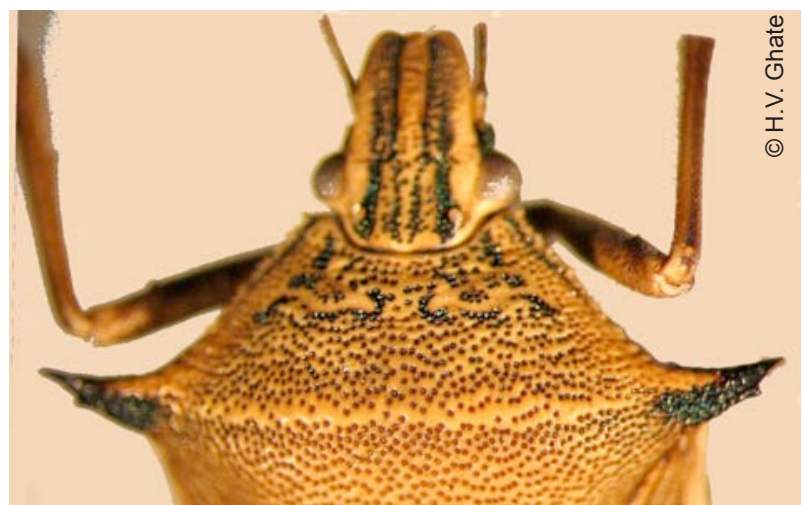

Image 3a. Andrallus spinidens: close up of head and pronotum. Dorsal view showing lateral pronotal spines and impunctate pale line joining the two, crenulations of lateral border and pattern of black punctures near pronotal calli

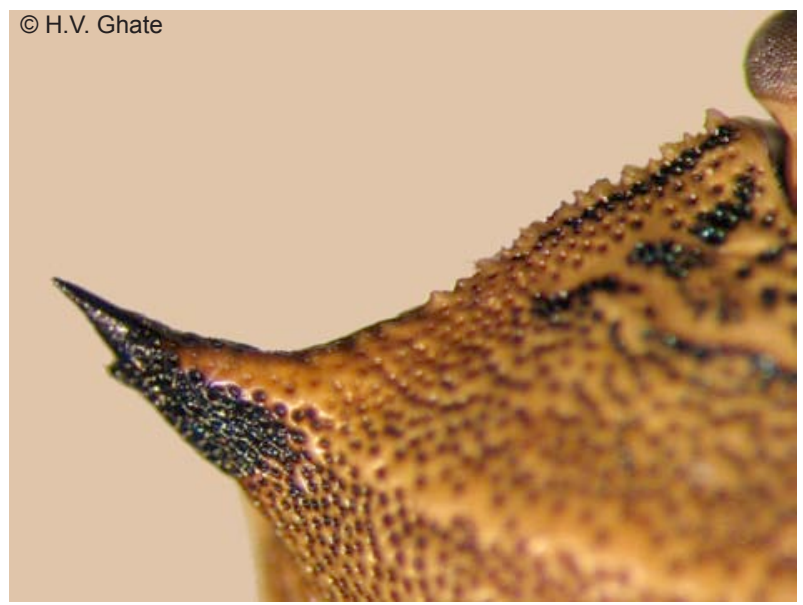

Image 3b. Andrallus spinidens: further close up of pronotum (dorsal view) showing lateral pronotal spine and coarse black punctures at its base along with short spine. Note also the crenulations of anterio-lateral border

a pale impunctate line extends from the centre of the apical region to the distal end of the scutellum (Image 4). Corium shows dense black punctures, appearing darker than pronotum, with a broad luteous stripe at the side all along its length. Hemelytral membrane smoky with darker parallel veins. The connexivum is dark brown to blackish, the external margins of which are narrowly pale.

Ventrally, head is pale with coarse punctures; pro, meso and metasternum are densely punctured, punctures are black in the lateral region and light brown in the median region. A squarish area between fore and mid coxae is pale and impunctate. Sternum also with a median, longitudinal and flattish carina. All legs are pubescent with very fine white hairs (Image 5). All 


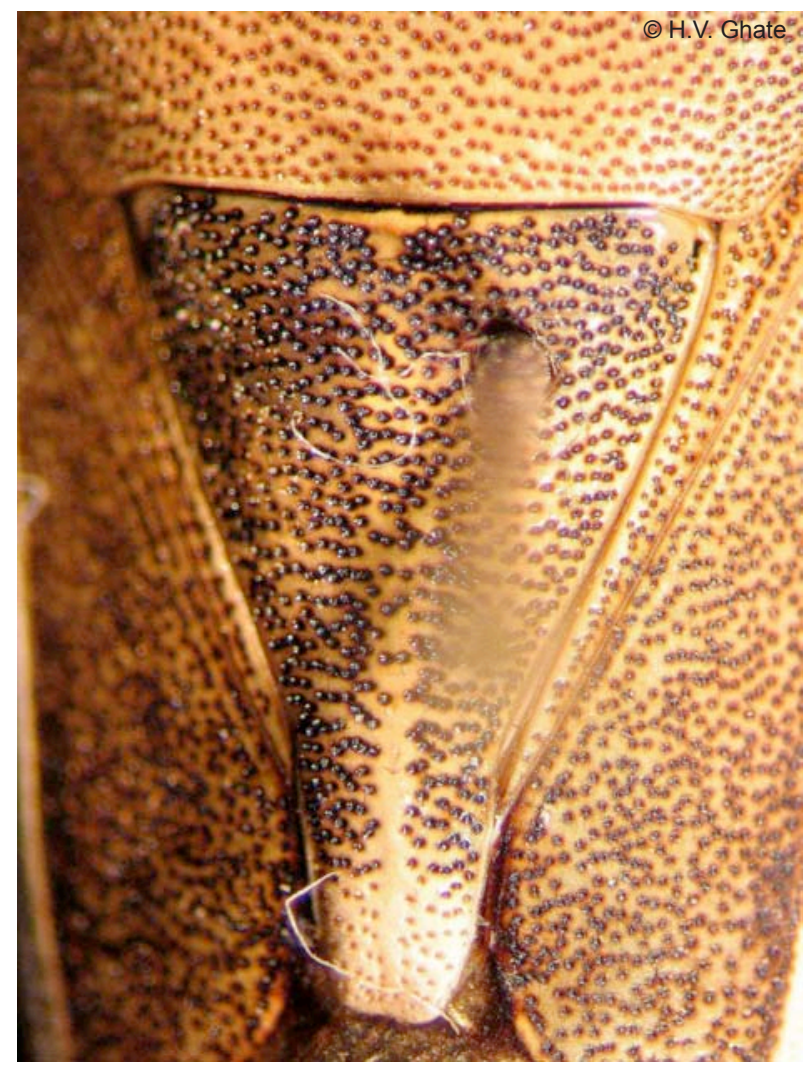

Image 4. Andrallus spinidens: scutellum close up showing relatively dark coarse punctures in basal area and clear central line as well as an apical colorless area with punctures

legs have femora and tibia pale yellow colored, while the tarsal segments are dark blackish-green, ventrally femora coarsely punctured in all legs, anterior femora spineless. Abdomen coarsely punctured with a series of dark median spots in the anterior most part of each abdominal segment. Some spots elongate and extend as a broad line up to or beyond the segment, $2^{\text {nd }}$ abdominal segment almost wholly covered with black punctures, spiracles and a series of lateral spots close to spiracles, also black (Image 6). The rostrum is relatively stout, four segmented, extends up to hindcoxae and is pale except at the tip which is black (see Image 5).

Specimen examined: November 2010, one, coll. Y. Koli. The total length of the studied specimen is $16.5 \mathrm{~mm}$ (head to tip of the membrane), $14 \mathrm{~mm}$ (head to end of the body), and breadth between pronotal spines is $8.5 \mathrm{~mm}$.

There is only a single species described and illustrated under the genus Audinetia in Distant (1902). It is also easily recognizable because of its

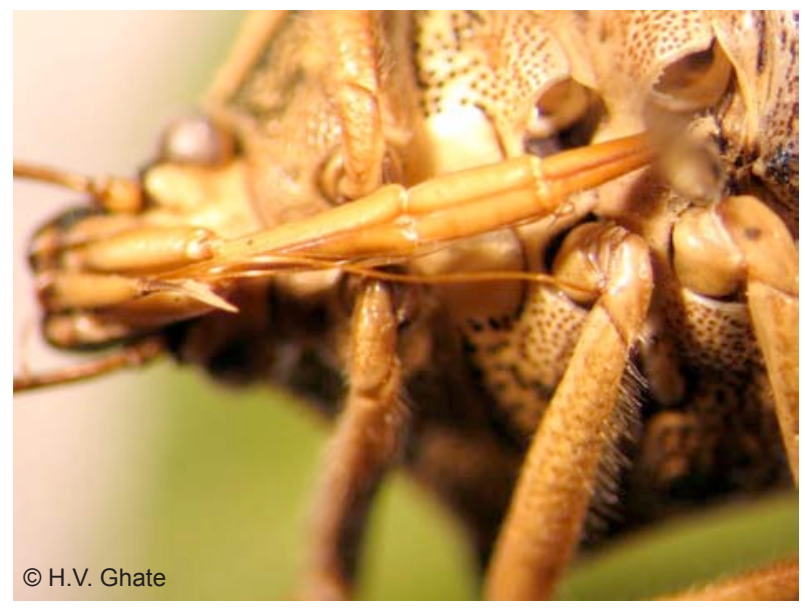

Image 5. Andrallus spinidens: ventral view of anterior region showing robust rostrum and hairy legs

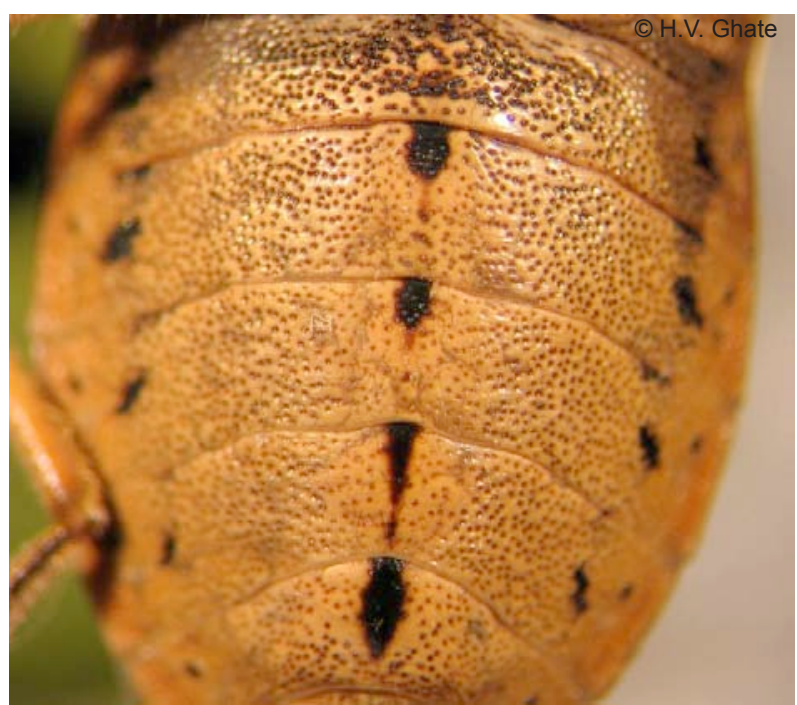

Image 6. Andrallus spinidens: abdomen (ventral view) showing characteristic pattern of black coloration and coarse punctures.

typical dorsal colouration. It is a carnivorous bug and a well known biological control agent, especially on lepidopteran larvae (Manley 1982).

The other bug Sabaeus humeralis (Fig. 7) (Pentatomidae: Pentatominae) can be diagnosed due to the following characters: body obovate, thickly and coarsely punctuate; color dark or olivaceous green and shining on most parts of the body; head inclined and narrowed anteriorly, with sinuate lateral margins, lateral and median lobes of almost equal length. Lateral lobes of head and a small area behind each lateral spine, reddish-ochraceous, a fine black line borders the outer margin of the lateral lobes while the 


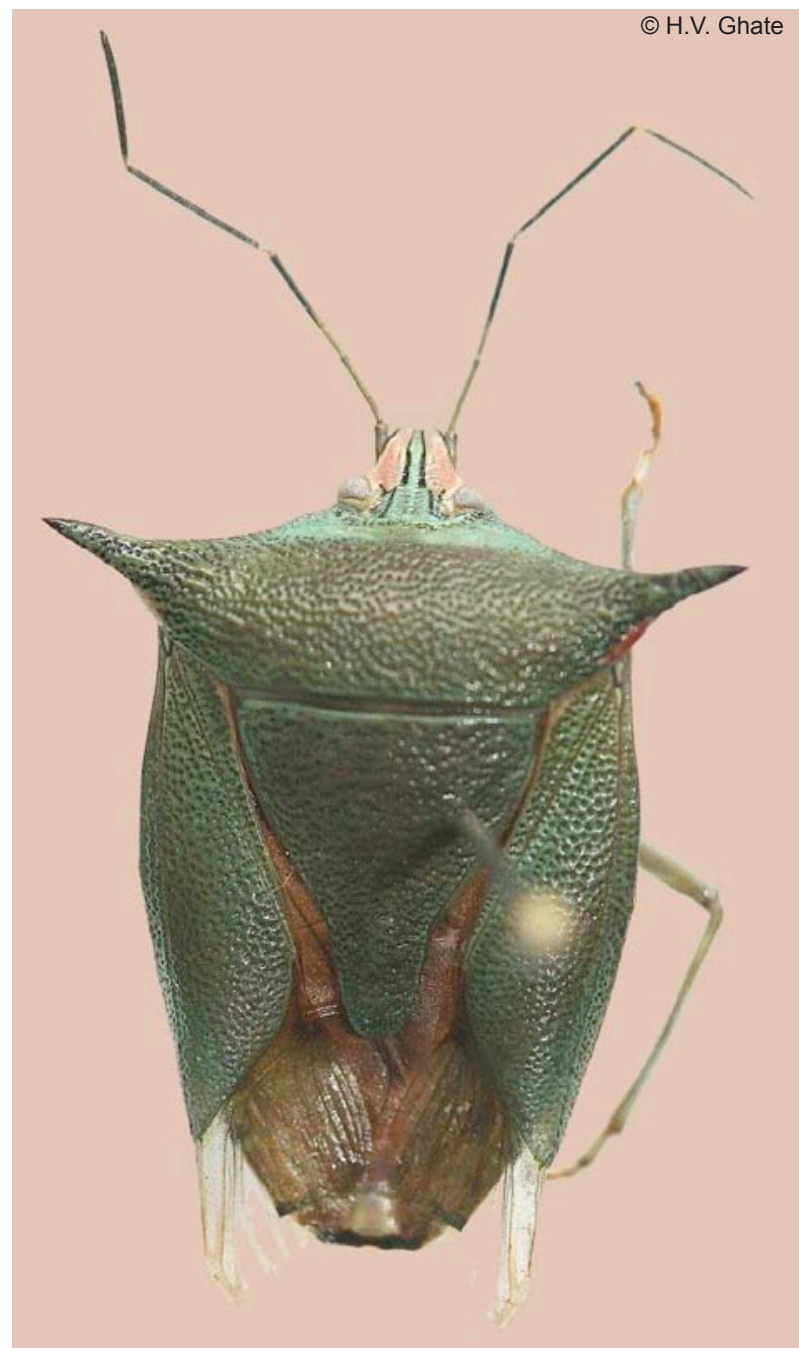

Image 7. Sabaeus humeralis, dorsal view.

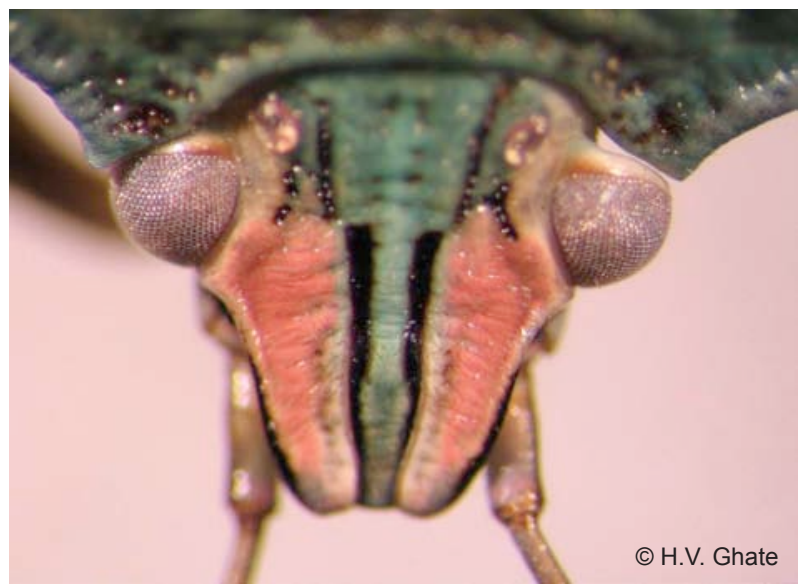

Image 8a. Sabaeus humeralis: head, dorsal view showing reddish-ochraceous lateral lobes, separated from central lobe, by black lines

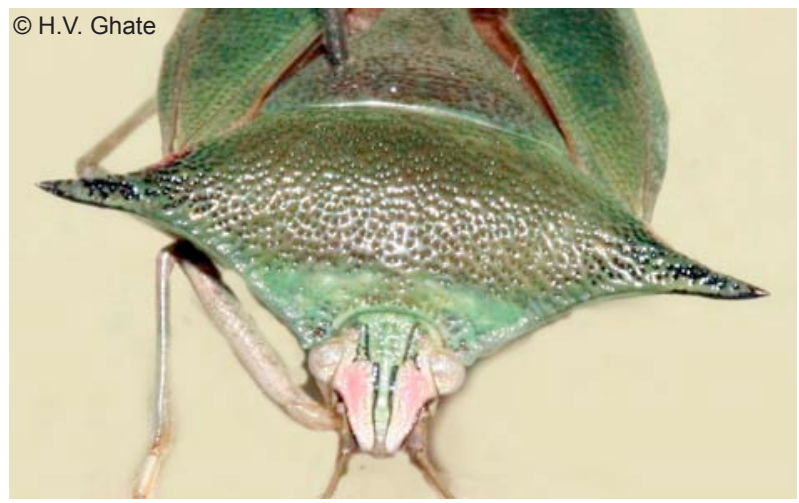

Image 8b. Frontal view of Sabaeus humeralis showing details of pronotum median lobe is distinguished from the lateral lobes by distinct black lines that extend in length behind up to an imaginary line joining median point of the eyes. The dorsal side of the head is transversly striated. A fine vertical line of black punctures is present on the inner side of each ocellus, with a short oblique line of black punctures in front of each ocellus (Image 8a). Antennae are dark green, with $3^{\text {rd }}, 4^{\text {th }}$ and $5^{\text {th }}$ segments distinctly darker with basal parts pale greenish. The $1^{\text {st }}$ antennal segment reaches the tip of the head. Pronotum obliquely deflected anteriorly, with spinelike, produced lateral angles (Image 8b). Anterior $1 / 4^{\text {th }}$ region of pronotum distinctly pale green, strongly contrasting with rest of pronotum ground colouration, the pale green colour extending along the median lobe of the head (see Image 8b). Many punctures on pronotum, especially on lateral spines and some parts of scutellum, are dark black. The area between punctures shining green, almost like beetle elytra. Spines of the lateral pronotal angles are green with black tips and possess a reddish ochraceous spot at the posterior margin (Image 9). Ventrally these spines are smooth, pale green and with black tips (Image 10). Scutellum narrowed towards apex. Corium dark green, hemelytral membrane translucent pale green.

Ventral side is light green in lateral parts, pale cream in the median region, especially in abdominal area. Legs are pale green. Fine, sparse punctures are present on some parts of the sternum. Mesosternum distinctly carinate. Rostrum green, except the tip which is black, reaching beyond the $2^{\text {nd }}$ abdominal segment. Tips of the posterior angles of each abdominal segment dark black and produced as a minute spine (Image 11). A short, obtuse ventral abdominal spine is present on II 


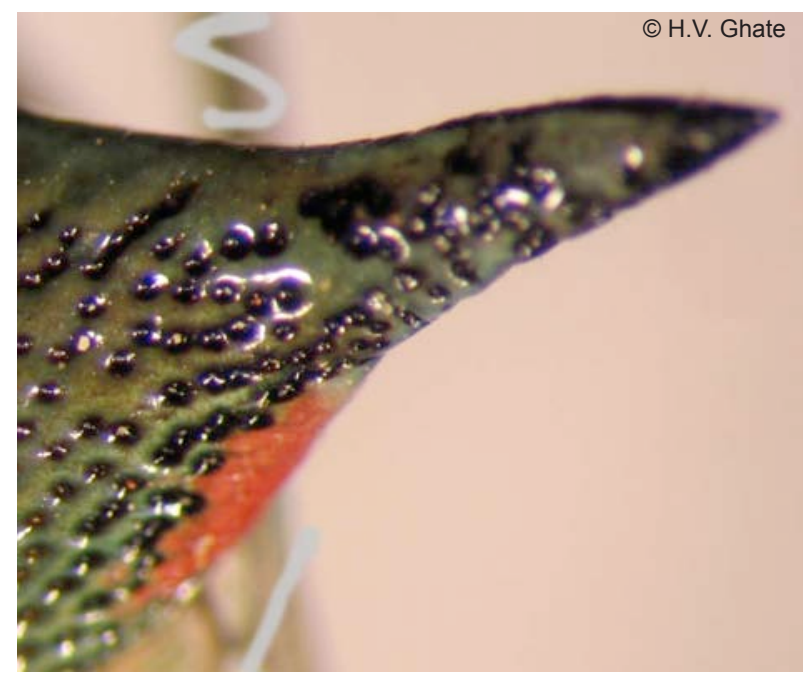

Image 9. Sabaeus humeralis: close up of pronotal angle (dorsal view) showing dark punctures between shining green area with reddish ochraceous spot on posterior margin

abdominal sternite.

Specimen examined: November 2010, one, coll. Y. Koli. The total length of the studied specimen is $17.5 \mathrm{~mm}$ (from head to tip of the membrane and $16 \mathrm{~mm}$ to the tip of abdomen) and breadth between pronotal spines is $15 \mathrm{~mm}$.

The species Sabaeus humeralis is the only species described in Distant's Fauna (1902). According to Distant, the bug is known from Assam and also from Burma (now Myanmar), extending east to China and this find represents a significant southwesterly addition to its known range in India.

It appears that these two species are an addition to the known species of Pentatomidae from Maharashtra, at least on the basis of distribution given by Distant (1902). We are not aware of any previous, published checklist/specific surveys for Pentatomidae of Maharashtra. We feel that extensive surveys and taxonomical works on bugs in Maharashtra are likely to add further to the known number of Pentatomidae species.

We hope that the digital images of the prominent characters, provided with this note, will help any naturalist in identifying these bugs.

\section{REFERENCES}

Distant, W.L. (1902). The Fauna of British India including

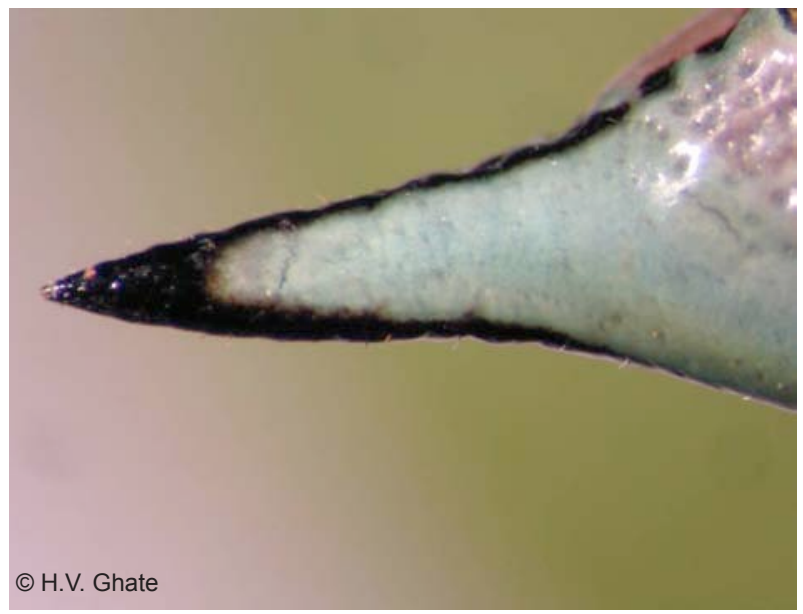

Image 10. Sabaeus humeralis: close up of pronotal spine (ventral view) with black tip

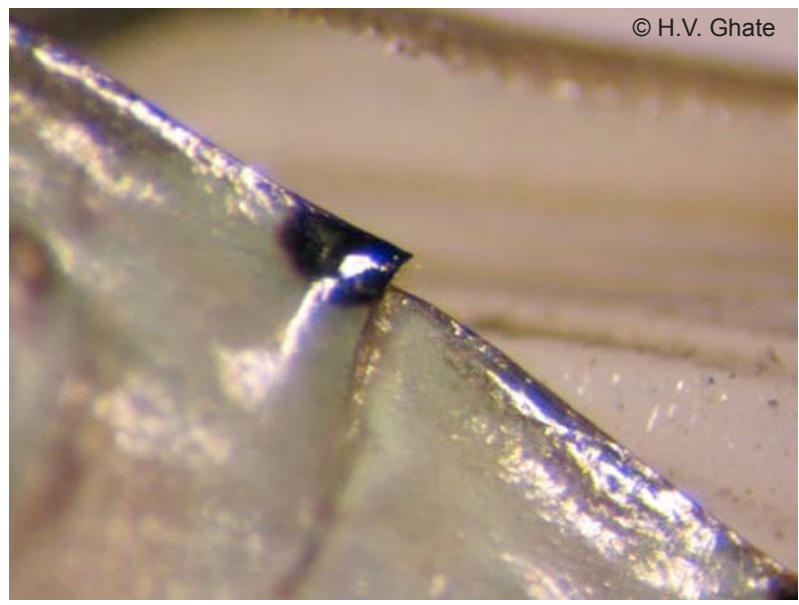

Image 11. Ventral view of Sabaeus humeralis abdomen showing the spiny tips at the posterior angle of each segment

Ceylon and Burma - Rhynchota-Volume 1 (Heteroptera). Taylor and Francis, London, 438pp. (Indian Reprint Today and Tomorrows Printers and Publishers New Delhi 1977).

Manley, G.V. (1982). Biology and life history of the rice field predator Andrallus spinidens F. (Hemiptera: Pentatomidae), Entomological News 93: 19-24.

Pericart, J. (2010). Hemipteres Pentatomoidea Euro Mediterraneens 3: Podopinae et Asopinae. Faune de France 93. Federation Francaise des Societes de Sciences Naturelles, Paris, 291pp.

Thomas, D.B. (1992). Taxonomic Synopsis of The Asopine Pentatomidae (Heteroptera) of The Western Hemisphere. Thomas Say Monograph 16, Maryland, 156pp.

Thomas, D.B. (1994). Taxonomic synopsis of the Old World asopine genera (Heteroptera: Pentatomidae). Insecta Mundi 8(3-4): 145-212. 